Journal of Education, Teaching, and Learning is licensed under

A Creative Commons Attribution-NonCommercial 4.0 International License.

\title{
MODIFICATION OF TRIANGLE RUN EXERCISE TO IMPROVE THE ENDURANCE OF CRICKET ATHLETE
}

\author{
Memet Muhamad $^{1)}$, Mia Kusumawati ${ }^{2)}$, Aridhotul Haqiyah ${ }^{3)}$, Herlina Ulfah Rosadi ${ }^{4)}$ \\ 1) Universitas Islam 45 Bekasi, Bekasi, Indonesia \\ E-mail:memet@unismabekasi.ac.id \\ 2) Universitas Islam 45 Bekasi, Bekasi, Indonesia \\ E-mail:miasubarno@gmail.com \\ 3) Universitas Islam 45 Bekasi, Bekasi, Indonesia \\ E-mail: aridhotulhaqiyah@yahoo.com \\ 4) Universitas Islam 45 Bekasi, Bekasi, Indonesia \\ E-mail: herlina.ulfah@gmail.com
}

\begin{abstract}
This study aims to determine the effect of modification of triangle run exercises on endurance of male cricket athletes in Bekasi. This research method uses the experimental method. The population and sample in this study were all male cricket athletes with 14 people. The researcher used the total sampling technique or the whole to be sampled. The results of this study indicate that the factor of triangle run training can have a significant effect on endurance in male cricket athletes in Bekasi with the results of $\mathrm{t}_{\text {count }}=5.24$ in $\mathrm{p}>0.05$.
\end{abstract}

Keywords: Modification of triangle run exercise; Endurance; Cricket Athlete

\section{INTRODUCTION}

Sports is an active behavior that activates metabolism and influences the benefits of glands in the body to produce the immune system to protect the body from disease and stress problems. Therefore, everyone should do sports activities in an organized and well-structured manner. In many types of sports include games and sports, developmental activities, gymnastic activities, rhythmic activities, water activities. Sports games include athletics, basketball, soccer, table tennis, self-defense, cricket, and other activities.

Cricket are from England and are played in summer that has long been known to the world community, especially countries with historical backgrounds that adopt the culture and British traditions, such as India, Pakistan, Australia and so on. Cricket This already exists in Indonesia. In the literature on the eruption of Mount Krakatau and the life of the people of Jakarta mentioned the existence of a game cricket between the Batavian Cricket Club and guests of the Circus Eleven in the Monas area.

Bowler, Betting, Fielding are important requirements in this game. In cricket is a sport that does not require time in the match, but is determined by over. Cricket is a team sport which consists of several game numbers such as 20 (twenty) played consisting of 11 players, 8 (eight) consisting of 8 players, 6 (six) consisting of 6 players. Cricket is almost similar to baseball. However, baseball sports are local while cricket is international.

Cricket is a sport in which fitness is traditionally not thought of as very important. The importance of fitness in any sport cannot be underlined. The fitter you are the better you'll play. But Cricket is one such sport which tests your game skills, mental strength, stamina and physical endurance as well (Wood, 2008).

Physical condition is one of the important conditions in improving an athlete's achievement, by having a good physical condition, an athlete can optimize his abilities when playing in a game (Rahmad, 2016). Elements of 
physical conditions such as strength, strength, speed, agility, balance, coordination and flexibility are elements needed in every sport, both individual and group sports (including teams) including cricket (R. \& K., 2017).

Endurance is one of the important elements needed in Cricket (Mr. Ravi Vishwanath Gola \& Dr. Hanumantayya Pujari, 2019). Infield observations on January 12, 2018, there was almost all the male athlete's cricket in Bekasi City lacking good endurance when playing, because in games cricket the endurance function is very important to master a game that has no time limit but uses over (after the ball sixth).

To improve the ability of athletes in his team to have good endurance, the coach can develop through training methods, one of which is a triangle run that is rarely used by coaches, this endurance training method is an endurance aerobic exercise. Aerobic endurance functions to overcome the burden of exercise in more than three minutes continuously. It was concluded that both aerobic and anaerobic training groups have significantly improved the speed and cardio respiratory endurance of the cricket players. However, anaerobic training is significantly better than aerobic training in improving speed and aerobic training is significantly better than anaerobic training in improving cardio respiratory endurance of the cricket players (Dr. A. Gunalan, 2019; Kunwar Bipin Pratap Bhushan, Neeru Nathani, 2017; Noakes \& Durandt, 2000). Based on the explanation above, the researcher wants to use endurance exercise triangle run on the male athlete cricket in Bekasi.

\section{Methodology}

The method used is the experimental method. According to Salso \& Maclin experimental research is a study in which found at least one variable that is manipulated to study the causal relationship (Kusumawati, 2015). Therefore, experimental research is closely related to testing a hypothesis to look for influence, relationships, and differences in changes to the groups subject to treatment.

The sample is part of the number and characteristics possessed by the population (Kusumawati, 2015). Therefore, experimental research is closely related to testing a hypothesis to look for influence, relationships, and differences in changes to the groups subject to treatment. According to the authors of experimental research is research conducted on samples until there are changes that occur or not.

The sample is part of the number and characteristics possessed by the population (Kusumawati, 2015). Samples were taken were male athletes cricket totaling 14 homogeneous people. Treatment used in this study was modification of triangle run exercise with the diagram in Fig. 1.

The instrument used in this study was the bleep test (Widiastuti, 2015). Cardiorespiratory fitness (20-meter shuttle run test or Bleep test). In this test, the initial speed is $8.5 \mathrm{~km} / \mathrm{h}$ and it is increased by $0.5 \mathrm{~km} / \mathrm{h}$ per $\min (1 \mathrm{~min}$ equals one stage). The subjects ran in a straight line, to pivot upon completing a shuttle and to pace themselves in accordance to the audio signals given. The test is finished when the subject stops or fails to reach the end lines concurrent with the audio signals on minutes of tactical/technical training and set plays. The two consecutive occasions. The equation of Léger and postseason and the off-season were not supervised (Berdejodel-Fresno, 2012).

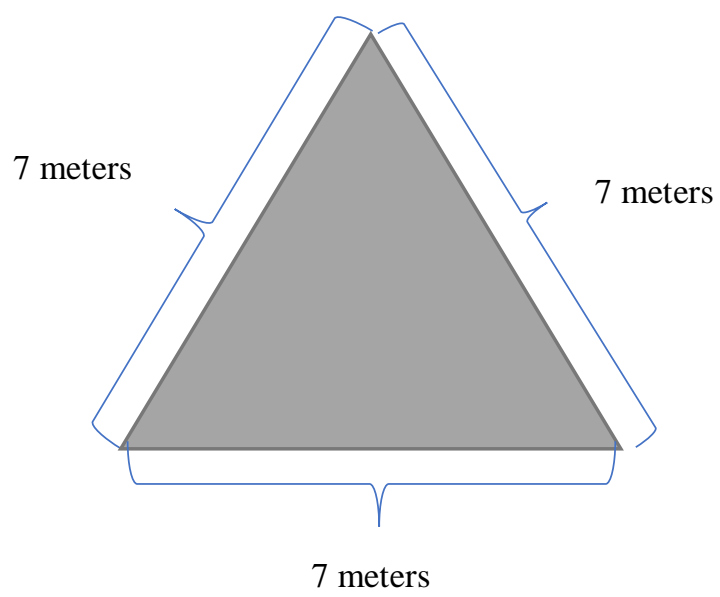

Fig. 1 Diagram of Modification of Triangle Run Exercise

\section{RESULTS AND DISCUSSION}

The results of the calculation of descriptive statistics (Muhamad, Memet; Aridhotul, 2015) are presented in Table I. Based on the descriptive statistical tests above, it can be seen that the post-test results are greater so that there is an increase in endurance with an average value of 2.83 .

TABLE I

DESCRIPTIVE STATISTICS

\begin{tabular}{lccc}
\hline \multicolumn{1}{c}{ Group } & $\sum \boldsymbol{\chi}$ & $\overline{\mathbf{X}}$ & $\mathbf{S}$ \\
\hline Pre-test & 565.6 & 40.4 & 5.7 \\
Post-test & 605.2 & 43.2 & 4.65 \\
\hline Gain & $\mathbf{3 9 . 7}$ & $\mathbf{2 . 8 3}$ & $\mathbf{2 0 . 4}$ \\
\hline
\end{tabular}

After the calculation of each data, the next step is to test the normality test with the Lilliefors test. The results of the calculation of the analysis of the normal distribution and the data set are presented in Table II.

TABLE II

NORMALITY TEST

\begin{tabular}{lccc}
\hline \multicolumn{1}{c}{ Group } & Lo & L $_{\text {table }}$ & Result \\
\hline Pre Test & 0.1112 & 0.227 & Normal \\
Post Test & 0.1041 & 0.227 & Normal \\
\hline Gain & $\mathbf{0 . 0 9 8 7}$ & $\mathbf{0 . 2 2 7}$ & Normal \\
\hline
\end{tabular}

From the results of the calculation of each of the data sets above, concludes that the hypothesis is accepted because all Lo Calculate $<\mathrm{L}_{\text {table }}$, where Lo table at the real level $(\alpha)=0.05$ and $n=14$ is 0.227 so the distribution of the data sets is normal. Carry out the Homogeneity Test of 
the data set to find out whether the data is homogeneous or not (see Table III).

TABLE III

HOMOGENEOUS TEST

\begin{tabular}{cccc}
\hline Variable & F-count & F-table & Result \\
\hline Endurance & 1.50 & 2.89 & Homogeneous \\
\hline
\end{tabular}

Based the table results obtained F count compared with $F$ table with degrees of freedom for the numerator 13 and the denominator 13 levels $\mathrm{L}=0,05$ obtained $\mathrm{F}$ table 2.89 because of the test results obtained by the calculated $F$ value <of the $\mathrm{F}$ table then the data is received. This means that the test results are homogeneous distribution.

After the homogeneity test data obtained an outcome, then the next is to calculate the t-test. T-test was conducted to test whether the training method modification $\mathrm{f}$ triangle run showed significant improvement results (there was a significant increase) or there was no increase. From the results of the calculation of the t-test above, then the income of a data or results as listed in the calculation of the table IV.

TABLE IV

HYPOTESIS TESTING

\begin{tabular}{cccc}
\hline Variable & t-count & t-table & Result \\
\hline Endurance & 5.24 & 2.16 & Significant \\
\hline
\end{tabular}

Based on the analysis the data above proves that training of triangle run can have a significant effect on the endurance of male athletes cricket. The following is a calculation of the effect of the exercise triangle run on endurance obtained by $t$-count $=5.24$ which is greater than $\mathrm{t}$-table $=2.16$ so that Ho was rejected there was a significant increase, at a significant level $\alpha=0.05$ and $\mathrm{dk}=$ 13. This illustrates that training triangle run can improve the endurance of male athletes cricket in Bekasi (see Table $\mathrm{V})$.

TABLE V

THE RESULT OF PRE-TEST

\begin{tabular}{lccc}
\hline \multicolumn{1}{c}{ Criteria } & 18-25 Years & Frequency & Percentage \\
\hline Excellent & $>60$ & 0 & $0 \%$ \\
Good & $52-60$ & 0 & $0 \%$ \\
Above Average & $47-51$ & 3 & $21,43 \%$ \\
Average & $42-46$ & 3 & $21,43 \%$ \\
Below Average & $37-41$ & 5 & $35,71 \%$ \\
Poor & $30-36$ & 3 & $21,43 \%$ \\
Very Poor & $<30$ & 0 & $0 \%$ \\
\hline
\end{tabular}

The results from the initial multi-stage running test calculation of 14 male cricket athletes in Bekasi City are described Table VI. Based the results of the processing and analysis of data it can be seen that the results of the exercise effect triangle run on the endurance athletes cricket of Bekasi City provide answers to the problems raised in the study.

The training process triangle run has a positive effect on endurance in athletes cricket male Bekasi. There has been an increase due to routine and programmed training programs increasing. Factors that influence improvement include physical condition, fit, routine and programmed training, intake of nutrients and vitamins are maintained (Jeukendrup, 2011), adequate facilities and infrastructure and cricket mental toughness inventory(Gucciardi \& Gordon, 2009) in athletes who want endurance is much better and added with advice and direction trainer.

TABLE VI

THE RESUlT OF POST-TEST

\begin{tabular}{lccc}
\hline \multicolumn{1}{c}{ Criteria } & 18-25 Years & Frequency & Percentage \\
\hline Excellent & $>60$ & 0 & $0 \%$ \\
Good & $52-60$ & 3 & $21,43 \%$ \\
Above Average & $47-51$ & 2 & $14,29 \%$ \\
Average & $42-46$ & 7 & $50 \%$ \\
Below Average & $37-41$ & 1 & $7,14 \%$ \\
Poor & $30-36$ & 1 & $7,14 \%$ \\
Very Poor & $<30$ & 0 & $0 \%$ \\
\hline
\end{tabular}

\section{CONCLUSIONS}

The results of this study can be concluded that the factor of triangle run training can have a significant effect on endurance in male cricket athletes in Bekasi with the results of $\mathrm{t}_{\text {count }}=5.24$ in $\mathrm{p}>0.05$.

\section{REFERENCES}

Berdejo-del-Fresno, D. (2012). Fitness Seasonal Changes in a First Division English Futsal Team. African Journal of Basic \& Applied Sciences, 4(2), 49-54. https://doi.org/10.5829/idosi.ajbas.2012.4.2.537

Dr. A. Gunalan. (2019). Analysis Of Aerobic Training Versus Anaerobic Training Impact On Selected Bio-Motor Abilities Of Cricket Players. Review Of Research. https://doi.org/10.9780/2249894X

Gucciardi, D. F., \& Gordon, S. (2009). Development and preliminary validation of the cricket mental toughness inventory (CMTI). Journal of Sports Sciences. https://doi.org/10.1080/02640410903242306

Jeukendrup, A. E. (2011). Nutrition for endurance sports: Marathon, triathlon, and road cycling. Journal of Sports Sciences. https://doi.org/10.1080/02640414.2011.610348

Kunwar Bipin Pratap Bhushan, Neeru Nathani, N. S. T. (2017). Impact of Bhramari Pranayama on Cardio Respiratory Endurance among the Cricket Players with Special Reference to Prakriti (Psychosomatic Constitution). International Journal of Physical Education and Sports.

Kusumawati, M. (2015). Penelitian Pendidikan Penjas. Bekasi: eQuator.

Mr. Ravi Vishwanath Gola, \& Dr. Hanumantayya Pujari. (2019). Impact Of Self Esteem On Sports Performance Of Cricket Players. Review of Research Journal. https://doi.org/10.9780/2249894X

Muhamad, Memet; Aridhotul, H. (2015). Diktat statistik olahraga. FKIP: UNISMA Bekasi. 
Noakes, T. D., \& Durandt, J. J. (2000). Physiological requirements of cricket. In Journal of Sports Sciences.

https://doi.org/10.1080/026404100446739

R., J., \& K., D. (2017). Physiological monitoring of sports personnel. Indian Journal of Physiology and Pharmacology.

Rahmad, H. (2016). Pengaruh Penerapan Daya Tahan Kardiovaskuler (Vo Max) dalam Permaian Sepakbola PS Bina Utama. Curricula. https://doi.org/10.22216/jcc.v2i2.1009

Widiastuti. (2015). Tes dan pengukuran olahraga. Tes Dan Pengukuran Olahraga. https://doi.org/10.1002/jmv.10345

Wood, R. (2008). Cricket Fitness. 